\title{
PROGRESS IN INFORMATION TECHNOLOGY AND TOURISM MANAGEMENT: A CRITICAL REVIEW
}

\author{
Estika Paramita Sani ${ }^{1}$, Anton P.W Nomleni ${ }^{2}$ \\ ${ }^{I}$ Manajemen,Universitas Matana, Tangerang, estika.paramita@matanauniversity.ac.id \\ ${ }^{2}$ Manajemen,Universitas Matana, Tangerang, anton.nomleni@matanauniversity.ac.id
}

\begin{abstract}
:
The present paper offers a review of an article written by Buhalis and Law (2008). The article sytematically described about how technology improvementhas changed all fundamental sectors particularly in tourism. Recently, the demand of tourism should accommodate by tourism organizations by adopting technology in their production processes. This is due to the change of tourist characters started from 1990s. Nowadays, tourists tend to be more independent and prevent the common tourism behavior; backpacking is one of the products of independent tourism. Most tourists nowadays are looking for more value from the tourism activities according to their preferences. This current phenomenon can be further elaborated on what technologies should be adopted by tourism organizations to make tourism industry more advance and fit with the demand. This paper is a critical review of Buharis and Law writing in 2008. In conducting this research we use qualitative research.
\end{abstract}

Keywords: technology, tourism, critical review

\section{INTRODUCTION}

Among many sectors that occur in the tourism industry, 'innovation' and 'technological change' have begun to occupy a privileged place and it is greatly that they are here to stay and continue growing. It is predictable, since technology is one of the tools in improving business and destination competitiveness as well as to improving the tourist's experience. The advances in connectivity and processing power that have been made in ICT in recent years are obvious. It is also true that the expansion of technology is a great challenge in during this century, the phenomenon of the existence of ICT will bring us closer to becoming the more equal and cohesive society that we dream of, in which access to the Internet really does become a citizen's right and which contributes to democratization and to widening the horizons of citizen participation. Therefore, this paper is a critical review of an article entitled Progress in Information Technology and Tourism Management: 20 years on and 10 years after the Internet The state of eTourism Research written by Dimitrios Buhalis and Rob Law in 2008. In this paper we would like to review the accuracy of a paper written by Buhalis and Law in the current tourism industry. In conducting the review of Buhalis and Law, this paper is using qualitative research. Qualitative Research is ganerally exploratory research. It is used to get the understanding of hidden reason, motivation and opinion. It provides observation into the problem or helps to develop ideas for posibble quantitative research. Buhalis is a professor in strategic management and marketing specialized in technology and tourism. In this paper, Buhalis together with Law (2008) reviewed some eTourism issues related to technology in tourism 20 years prior to 2007. Using various 


\section{National Conference of Creative Industri: \\ Sustainable Tourism Industri for Economic Development}

Universitas Bunda Mulia, Jakarta, 5-6 September 2018 e-ISSN No: 2622-7436

sources which are derived from tourism literature, Buhalis and Law's comprehensively reviews and analyzes the application of the Internet in tourism.

In the introduction, Buhalis and Law write about the growth of tourism that goes hand in hand with the growth of technology. Since the 1980s, Information Communication Technologies (ICTs) has transformed the tourism industry both in terms of practices and strategies used. These ICTs ultimately have an extraordinary impact on the growth and development of tourism industry. Based on UNWTO (2001), ICTs are emphasized to play important roles in the competition among tourism organizations and tourist destinations as occurs in other industries. ICTs have changed the effectiveness and efficiency of tourism organizations radically. This is because more new players are appeared in the tourism industry, market share shifts and market forces, changes in political perceptions of tourism, and recognition of the importance of tourism for a country's economy.

ICTs can assist consumers in identifying, designing, and buying tourism products. In addition, ICTs are able to support the process of industry globalization by providing effective tools for the providers to develop, manage and distribute their offerings worldwide. The impact is an increasing area of research in the field of tourism. Buhalis and Law said that up to 1990, there are only few literatures on tourism. However, the rapid development of telecommunication technology increased the number of publications by $275 \%$. The research that are often done today is the influence of the internet on distribution, the influence of internet on price, and the influence of the internet on the interaction between users.

We basically agree with what Buhalis and Law have written about the development of ICTs today. But in our opinion, Buhalis and Law are less clear in giving an overview of how ICTs change the tourism industry. If their writing is made in the present context, then one of the embodiments of ICTs that can be delivered is about the presence of financial technology. Financial technology makes it easy to access financial products and make transactions easier, safer and simpler. The financial products themselves as we know have been attached to various tourism services such as hotels, tickets, and so forth. Financial technology is existed in Indonesia because it is driven by the number of internet users. Based on the results of the 2016 survey of the Association of Internet Service Providers Indonesia (APJII), internet users reached 132.7 million people from a total of 256.2 million inhabitants of Indonesia. The use of digital technology has changed the behavior of society such as social interaction up to the process of buying and selling online (e-commerce). This encouragement makes the players in the field of financial industry to develop financial technology (diary.id) Outline of the Review

After the introduction, Buhalis and Law discussed about the dimensions of consumers and demand for tourism products. It is said that ICTs allow tourists to access accurate and reliable information about the prices and facilities of tourism products that will be purchased. Therefore, because of ICTs, the quality of the services will increase. ICTs put users in between their functionality and product delivery processes. It was also said that every tourist is different with different experiences, motivations, and desires. Tourists who come from countries that have economic capability will usually be the tourists that frequently visit and have a high demand for international products.

The development of ICTs, especially the internet, presents the new type of tourists. They tend to seek out the extraordinary values of money and time sacrificed. This type of tourist is not interested in following the mainstream like buying travel 


\section{National Conference of Creative Industri: \\ Sustainable Tourism Industri for Economic Development}

Universitas Bunda Mulia, Jakarta, 5-6 September 2018 e-ISSN No: 2622-7436

packages but looking for their own options and schedules. As a result, the tour package lost its market due to the emergence of this type of independent tourist. The experience and progress inherent in these independent tourists makes the need for education tourism is increased. Tourism organizations are also changing along with the increase of independent tourists. Tourism organizations like hotels, airlines, and travel agencies cannot ignore the role of the internet for the access.

We felt that what Buhalis and Law's review in consumers' dimension points and demand for tourist products was less profound. Their paper only mentioned about the emergence of new types of tourists who tend to be independent and make the role of the Internet is very important for tourism organizations. Buhalis and Law should better explore what are the needs arised from the existence of this new type of tourist. If you look at the current development of tourism, the need for tourist facilities should be emphasized. Tourism facilities are the completeness of the tourist destination that is needed to fulfil the needs of tourists in enjoying the tour (Suwantoro, 2004). In addition, it is also necessary to explore what difficulties experienced by the tourists. Although ICTs are quite advanced, but not all sectors can properly use it. In Indonesia, the main problem in utilizing ICTis human resources (HR). It is still difficult to find reliable human resources who can operate ICT well (Jamaludi, 2017).

Furthermore, in the writings, Buhalis and Law discussed about technological innovation. Technological innovation in hardware, software, and network development continues to be a selection for tourism organizations. Only a tourism organization capable of following technological innovations can compete in the industry. The rapid technological developments make ICTs more affordable, user-friendly, and enable users and tourism organizations to take advantage. A growing technological innovation drives a major change in information systems. Wireless and mobile networks are widely used to communicate between organizations and their functions. Therefore, ICTs become a holistic integration system of network equipment and software.

Buhalis and Law describe the types of technologies that provide innovative software and networks that can support organizations in improving communication between partners and customers. The first technology is interoperability and ontology. Werthner and Klein (1999) define interoperability as a provision for service from upstream to downstream in a consistent and predictable way. Interoperability allows partners to interact electronically with other partners with convenient methods and deliver the right information at the right time to the right users and at the right cost. Ontology represents a concept in a domain and the relationship between the concept and the software system that is the moderator.

The second technology is multimedia. Multimedia becomes one of the key developments affecting tourism. Tourism information requires an overview and graphics to provide a tangible image or experience for the trip planner. Using animations or video clips can enrich information and interaction. Unlike offline information, the Web allows people from all over the world to know the destinations through $3 \mathrm{D}$ virtual tours. The third technology is mobile and wireless technology. Wireless is a term widely used to describe telecommunications using electromagnetic waves to carry signals. The development of ICTs makes the use of mobile phones and pagers, global positioning system (GPS), home-remote control, and surveillance systems are widespread.

The forth technology is web design. Tourists expect a more informative, interactive, and attractive website (Chu, 2001). Kim and Lee (2004) classified the 


\section{National Conference of Creative Industri: \\ Sustainable Tourism Industri for Economic Development}

Universitas Bunda Mulia, Jakarta, 5-6 September 2018 e-ISSN No: 2622-7436

quality of web services into six dimensions: ease of use, usability, content, security, responsive, and personalization. A good website can bring tourists to consider continuing to dig up information and make tourism decisions. A tourism organization should continue to evaluate its website to ensure its website is efficient, precise, and useful to travelers.

In this section, Buhalis and Law further explain the types of technology adopted in the tourism industry. Until now, these technologies are still quite relevant but there is a lot of development. Technology such as pager now cannot be utilized again to the fullest. In using mobile phones, users cannot escape from the development of network technology. Currently, it has been developed 1G, 2G, 3G, and 4G network technology. $\mathrm{G}$ is an extension of Generation, while the number in front of it reflects its level. The higher the number in front of $G$ shows more capabilities and features in sending and receiving information (Gunawan, 2016).

Furthermore, Buhalis and Law discuss industry and business functions. (Law and Jogaratnam, 2005) suggest that technology can be part of the strategic planning process of a business if only the manager uses the technology completely. Furthermore, effective ICT applications require knowledge from the managers and operations staffs. ICTs should be used for strategic operations and management. The development of ICT has a direct impact on the competition between companies. They define two fundamental roots for competitive advantage such as differentiation and cost advantage (Porter, 2001). In fact, it is very important for tourism actors to proactively use ICTs to improve the quality of their services.

The emergence of the internet affects all five forces in Porter's (1980) model, as it changed the conditions of competition in the marketplace. The internet is changing the industry structure by altering barriers to entry, minimizing switching costs, revolutionizing distribution channels, facilitating price transparency and competition, while enhancing production efficiency (Kim, Nam, \& Stimpert, 2004). Buhalis and Law described how Porter demonstrates the changing of industry process because of the internet existence. The internet has enhanced the bargaining power of suppliers as it enabled them to monitor competitors and offer tailored and differentiated products.

Buhalis and Law state that marketing and distribution are the business functions mostly affected by the technological revolution. Technology supports organizations to develop their knowledge base to improve their management and marketing functions. Using the Web and the Internet as a marketing tool, tourism organizations can reduce costs, revenue growth, marketing research and database development, and customer retention. ICTs also transformed the distribution function to an electronic marketplace, where access to information and ubiquity is achieved, while interactivity between principals and consumers provides major opportunities.

Generaly, we agree on what Buhalis and Law expressed in this section. In fact, in addition to management needs, the right information system is needed to facilitate the existing business processes within the company. Centralized information systems and used by every division of the company will speed up the exchange of accurate information 'from' and 'to each' section. Thus, business processes that occur within the company become more effective and efficient.

\section{CONCLUSION}




\section{National Conference of Creative Industri: \\ Sustainable Tourism Industri for Economic Development}

Universitas Bunda Mulia, Jakarta, 5-6 September 2018 e-ISSN No: 2622-7436

Considering all this, we still see the relevance from the idea of Bulharis and Law in the current tourism industry. However, the rapid technological developments trigers research, writings, and publications that relate tourism sector with the development of technology, especially information technology. Information Technology is a technology used to process data, including processing, obtaining, compiling, storing, manipulating data in various ways to produce qualified informations that are relevant and accurate to be used for personal, business, government and decision maker. Information and Communication Technology (ICT) as part of science and technology, in general are related to the collection, processing, storage, dissemination and presentation of information. In Indonesia, tourism is one of the leading sectors of country's economic development. As a leading sector, tourism must be able to follow the changes in consumer behavior where consumers or tourists are becoming more digital. Therefore, studies on technology and tourism are still very necessary to be done especially in the country like Indonesia when tourism is one of the aspects that will be developed.

\section{REFERENCES}

Buhalis, D. \& Law, R. (2008). Progress in Information Technology and Tourism Management: 20 years on and 10 years after the Internet - The state of eTourism Research. Journal of Tourism Management, 29(4), 609-623.

Chu, R. (2001). What online Hong Kong travellers look for on airline/travel Websites?.International Journal of Hospitality Management, 20(I), 95-100.

Diary.id. retrieve from: http://ppmdiary.id/perkembangan-fintech-di-indonesia-part-1/).

Gunawan (2016). Teknologi Jaringan $1 \mathrm{G} \quad 2 \mathrm{G} \quad 3 \mathrm{G} \quad 4 \mathrm{G}<$ retrieved https://haiwiki.info/teknologi/definisi-jaringan-1g-2g-3g-4g/>

Jamaludin.F (2017). SDM masih jadi isu penting sektor teknologi informasi <retrieved https://www.merdeka.com/teknologi/sdm-masih-jadi-isu-penting-sektorteknologi-informasi.html>

Kim, W. G., \& Lee, H. Y. (2004).Comparison of service quality between online travel agencies and online travel suppliers.Journal of Travel \& Tourism Marketing, 17(2/3), 105-116.

Kim, E., Nam, D., \& Stimpert, J. L. (2004). The applicability of porter's generic strategies in the Digital Age: Assumptions, conjectures and suggestions. Journal of Management, 30(5), 569-589.

Law, R., \& Jogaratnam, G. (2005). A study if hotel information technology applications. International Journal of Contemporary Hospitality Management, 17(2), 170-180.

Perkembangan Fintech di Indonesia (Part 1). (2017, June 16). Retrieve from http://ppmdiary.id/perkembangan-fintech-di-indonesia-part-1/

Porter, M. (1980).Competitive strategy: techniques for analyzing industries and competitors. New York: Free Press.

Porter, M. (2001).Strategy and the Internet.Harvard Business Review, 79(3), 63-78. 
SDM masih jadi isu penting sektor teknologi informasi. (2017, May 10). Retrieve from https://www.merdeka.com/teknologi/sdm-masih-jadi-isu-penting-sektorteknologi-informasi.html

Suwantoro, G. (2004). Dasar-Dasar Pariwisata. Yogyakarta: Andi.

Teknologi Jaringan 1G, 2G, 3G, 4G. (2016, October 14). Retrieve from https://haiwiki.info/teknologi/definisi-jaringan-1g-2g-3g-4g/

UNWTO. (2001). eBusiness for tourism: Practical guidelines for destinations and business. Madrid: Wourld Tourism Organization.

\section{BIODATA}

Estika Paramita Sani was born in Boyolali on $6^{\text {th }}$ of March, 1990. She completed her undergraduate education at Sebelas Maret University in Surakarta. Then, she continued her education in Australia in 2014 at the University of Canberra majoring in International Business. During her study in Canberra, she attended many social activities and introducing of Indonesian culture to Australian citizen by performing the traditional dances and Indonesian music as well as helping Australian in learning Indonesian language. She began her career in the hospitality industry, at Abode Hotels Canberra in 2015 - 2016. Then, she developed a career in education as an Indonesian Language Assistent at Garran Primary School in 2016. After that she returned to Indonesia in 2017, she began lecturing at Matana University as a management lecturer. Estika also has an interest in the capital market industry. This interest led her to obtain certification as a Deputy Intermediary of Merchant Traders (WPPE).

Anton Petrus Weliand Nomleni was born on the $16^{\text {th }}$ of December 1960 . He completed his bachelor's degree at Indonesian Christian University (UKI). Then he continued his master's degree at Trisakti University with a major in management and he is currently pursuing his doctoral degree at Satya Wacana Christian University majoring in development economics. He has had a long career in education. He has taught in various campuses such as UKRIDA, STIE Kampus Ungu and is now a lecturer at Matana University. Aside from being a lecturer at Matana University, he also became dean of the Faculty of Economics and Business at Matana University. 